\title{
Zebrafish Embryonic Neurons Transport Messenger RNA to Axons and Growth Cones In Vivo
}

\author{
Marion Baraban, ${ }^{1,2,3}$ Isabelle Anselme, ${ }^{1,2,3}$ Sylvie Schneider-Maunoury, ${ }^{1,2,3 \star}$ and François Giudicelli ${ }^{1,2,3 \star}$ \\ ${ }^{1}$ CNRS, UMR7622, 75005 Paris, France, ${ }^{2}$ UPMC Univ Paris 06, 75005 Paris, France, and ${ }^{3}$ INSERM, U969, 75005 Paris, France
}

\begin{abstract}
Although mRNA was once thought to be excluded from the axonal compartment, the existence of protein synthesis in growing or regenerating axons in culture is now generally accepted. However, its extent and functional importance remain a subject of intense investigation. Furthermore, unambiguous evidence of mRNA axonal transport and local translation in vivo, in the context of a whole developing organism is still lacking. Here, we provide direct evidence of the presence of mRNAs of the tubb5, nefma, and stmnb2 genes in several types of axons in the developing zebrafish (Danio rerio) embryo, with frequent accumulation at the growth cone. We further show that axonal localization of mRNA is a specific property of a subset of genes, as mRNAs of the huc and neurod genes, abundantly expressed in neurons, were not found in axons. We set up a reporter system in which the $3^{\prime}$ untranslated region (UTR) of candidate mRNA, fused to a fluorescent protein coding sequence, was expressed in isolated neurons of the zebrafish embryo. Using this reporter, we identified in the $3^{\prime}$ UTR of $t u b b 5$ mRNA a motif necessary and sufficient for axonal localization. Our work thus establishes the zebrafish as a model system to study axonal transport in a whole developing vertebrate organism, provides an experimental frame to assay this transport in vivo and to study its mechanisms, and identifies a new zipcode involved in axonal mRNA localization.
\end{abstract}

\section{Introduction}

In neurons, the essential role of transport and local translation of dendritic messenger RNA (mRNA) in synaptic plasticity has long been recognized (Steward and Levy, 1982). Conversely, the absence of ribosomes in the presynaptic compartment originally suggested that axons, in contrast to dendrites, were devoid of local protein synthesis (Lasek et al., 1973). However, studies in recent years have established that axonal protein synthesis does occur during growth or regeneration of axons in culture (for review, Jung et al., 2012). It has been suggested in particular, that controlled translation of locally stored mRNA could provide the axonal growth cone with fine spatial and temporal responsiveness to its varying environment. In support of this hypothesis, presence of axonal mRNA populations has been demonstrated in diverse vertebrate neuronal types (Bassell et al., 1994; Twiss et al., 2000; Zheng et al., 2001; Lee and Hollenbeck, 2003; Leung et al., 2006; Kundel et al., 2009; Taylor et al., 2009; Glinka et al., 2010). Essential neuronal functions have been proposed to depend on

\footnotetext{
Received April 8, 2013; revised Aug. 8, 2013; accepted Aug. 24, 2013.

Author contributions: M.B. and F.G. designed research; M.B., I.A., and F.G. performed research; M.B., S.S.-M., and F.G. analyzed data; M.B., S.S.-M., and F.G. wrote the paper.

This work was supported by the Centre National de la Recherche Scientifique (CNRS), the Institut National de la Santé et de la Recherche Médicale (Inserm), the Université Pierre et Marie Curie and by fellowships from the Région lle de France (Neuropôle) and Fondation pour la Recherche Médicale (FRM) to M.B. We thank P. Affaticati for fluorescent in situ hybridization protocol; H. Baier for transgenic line; W. Talbot, N. Peyriéras and R. Collins for plasmids; R. Schwartzmann and J.-F. Gilles at the Cell Imaging microscopy facility of the IFR83; A. Bois, S. Tronche, and S. Authier for excellent fish care; S. Nédelec and members of the SSM laboratory for critical reading of the paper; L. Bally-Cuif and I. Caillé for fruitful discussions and anonymous reviewers for helpful suggestions.

The authors declare no competing financial interests.

*S.S.-M. and F.G. contributed equally to this work.

Correspondence should be addressed to Dr François Giudicelli, UMR7622, UPMC, 9 Quai Saint-Bernard, Bâtiment C 7 e étage, Case 24, 75252 Paris Cedex 05, France. E-mail: francois.giudicelli@upmc.fr.

DOI:10.1523/JNEUROSCI.1510-13.2013

Copyright $\odot 2013$ the authors $\quad 0270-6474 / 13 / 3315726-09 \$ 15.00 / 0$
}

axonal protein synthesis in these culture systems, including neuron survival (Cox et al., 2008), axon elongation and regeneration (Zheng et al., 2001; Verma et al., 2005), growth cone turning, and collapse (Campbell and Holt, 2001; Leung et al., 2006; Yao et al., 2006).

Although in several cases the $3^{\prime}$ untranslated region (UTR) of mRNA appears sufficient to drive axonal transport, remarkably little is understood about the underlying mechanisms. In particular, very few specific RNA elements have been characterized as required for transport. The most studied example is the so-called zipcode of the chicken $\beta$-actin mRNA, which is required for transport to axons (Zhang et al., 2001) and is associated to several protein factors including Zbp1/Imp1 (Ross et al., 1997).

The large corpus of studies demonstrating the importance of local translation of axonal mRNA in cultured neurons naturally brings the question of whether axonal mRNA transport and translation do also occur in vivo, when neurons grow their processes inside the complex meshwork of tissues of a developing organism. Due to the complexity of the nervous system in higher vertebrates and the small amount that axonal mRNA molecules represent, in vivo evidence of mRNA transport has proved difficult to obtain.

To resolve these questions, we sought to investigate the transport of mRNA molecules to the axonal compartment in a whole organism system amenable to imaging and easy transgenesis. We chose the developing zebrafish embryo as a suitable system fulfilling these requirements. Here, we provide direct evidence of the presence of mRNA in several types of axons in the developing zebrafish embryo, with frequent accumulation at the growth cone. We further show that axonal localization of mRNA is a specific property of a subset of genes, as other abundantly expressed neuronal mRNAs are absent from axons. We present an 
Table 1. List of candidate genes selected from published large-scale screens

\begin{tabular}{|c|c|c|c|c|c|c|c|c|}
\hline \multirow{2}{*}{$\frac{\text { Publication }}{\text { Method }}$} & \multirow{2}{*}{$\begin{array}{l}\text { Willis et al. (2007) } \\
\text { Membrane-separated compartments } \\
\text { CDNA array }\end{array}$} & \multirow{2}{*}{$\begin{array}{l}\text { Taylor et al. (2009) } \\
\begin{array}{l}\text { Microfluidic chamber } \\
\text { microarray }\end{array}\end{array}$} & \multicolumn{4}{|l|}{ Zivraj et al. (2010) } & \multicolumn{2}{|l|}{ Gumy et al., 2011} \\
\hline & & & $\begin{array}{l}\text { Laser microdissection } \\
\text { microarray }\end{array}$ & $\begin{array}{l}\text { Laser microdissectio } \\
\text { microarray }\end{array}$ & & & $\begin{array}{l}\text { Compartmentalized chamb } \\
\text { microarray }\end{array}$ & \\
\hline Species & Rat & Rat & Mouse & Xenopus & & & Rat & \\
\hline \multirow[t]{2}{*}{ Type of preparation } & \multirow[t]{2}{*}{ Injury-conditioned sensory axons } & \multirow[t]{2}{*}{ Cortical axons } & \multirow[t]{2}{*}{ Opticaxons } & \multicolumn{3}{|l|}{ Optic axons } & Embryonic sensory axons & Adult sensory axons \\
\hline & & & & st 28 Growth cones & st32 Growth cones & st32 Axons & & \\
\hline $\begin{array}{l}\text { Number of listed axonal mRNA species } \\
\text { Gene name (ZFIN symbol) }\end{array}$ & 206 & 310 & 2163 & 216 & 630 & 3202 & 2550 & 2412 \\
\hline $\begin{array}{l}\text { Neurofilament medium polypeptide } \\
\text { (nefma) }\end{array}$ & 178 & ND & ND & ND & ND & 1993 & 35 & 723 \\
\hline Tubulin beta 5 (tubb5) & ND & 219 & 366 & ND & ND & 158 & 932 & 361 \\
\hline Stathmin like 2b (stmn2b) & 38 & 121 & ND & 84 & 199 & 126 & 39 & 297 \\
\hline Hu antigen C (elav13) & ND & ND & ND & ND & ND & ND & 1283 & ND \\
\hline NeuroD (neurod) & ND & ND & ND & ND & ND & ND & ND & ND \\
\hline B-Actin (actb1; actb2) & 64 & 239 & 58 & ND & 87 & 108 & 67 & 91 \\
\hline
\end{tabular}

Numbers in the table represent the rank, in the ordered list of axonal mRNA species detected in each study, of the mRNA orthologous to the considered zebrafish gene. ND, Not detected.

experimental frame to assay the axonal transport of mRNA in vivo and use it to identify a novel axonal localization zipcode in the 3'UTR of $t u b b 5$ mRNA.

\section{Materials and Methods}

Plasmid constructs. All reporter constructs were made in a Bluescript SK backbone with flanking I-SceI restriction sites (Thermes et al., 2002). They comprise a promoter module (cloned from the pMaze plasmid in (Collins et al., 2010) made of 5 UAS sites followed by a minimal promoter and leader sequence, to which we grafted the coding sequence of myristoylated Venus or mCherry protein, directly followed by the 3'UTR sequence of choice, beginning with an EcoRI restriction site immediately after the endogenous stop codon. At its $3^{\prime}$ end, the $3^{\prime}$ UTR is followed by a NotI restriction site and a custom polyadenylation/transcription stop signal sequence (5' GCGGCCGCGGAATAAAACAAATGGTTTTGAA TTTAACATCTTTATAGTCGTTTCTGTAAAACTCTTCAtggtggtgcgtg 3'; uppercase letters indicate the residues incorporated into the mature transcript) copied from the zebrafish neuroD gene.

3'UTR sequences were PCR-amplified from IMAGE clone cDNAs when available: nefma (549 nt), stmn $2 b$ (884 nt), tubb5 (911 nt) or from genomic DNA: zebrafish actb1 (521 nt), actb2 (564 nt), huClelavl3 (1762 $\mathrm{nt})$, neuroD (1025 nt), mouse $\beta$-actin (733 nt), $\gamma$-actin (701 nt), and chicken $\beta$-actin (539 nt), flanked with EcoRI and NotI sites, and cloned into a single UAS:myr-Venus or UAS:myr-mCherry vector using these restriction enzymes. When a gene had ambiguous or multiple 3'UTRs, the longest sequence annotated in the UCSC database was used. Reference coding sequences of mCherry (Shaner et al., 2004), and Venus (Nagai et al., 2002) were used. Detailed sequences are available upon request.

Zebrafish strains, maintenance, and injections. Zebrafish were raised and maintained as described previously (Kimmel et al., 1995). Embryos of either sex were staged according to the number of hours postfertilization (hpf) or days postfertilization (dpf) at $28^{\circ} \mathrm{C}$. Zebrafish eggs of the $h u C: G a l 4$ transgenic line were obtained by crossing transgenic parents with wild-type mates. Plasmid DNA was injected into the animal cell at $1-2$ cell stage at $20 \mathrm{ng} / \mu \mathrm{l}$ in $1 \mathrm{X}$ I-SceI digestion buffer, complemented with $0.5 \mathrm{u} / \mu \mathrm{l}$ I-SceI meganuclease (Roche). The resulting transient transgenic embryos were sorted at $1-2 \mathrm{~d}$ for fluorescent protein expression in neurons.

Nocodazole treatments were performed essentially as described previously (Butler et al., 2010). Twenty-six hours postfertilization, embryos were transferred to E3 medium containing 0.5 or $1 \mu \mathrm{M}$ nocodazole (stock solution at $33 \mathrm{~mm}$ in dimethylsulfoxide (DMSO); Sigma-Aldrich, M1404), or 1/33000 DMSO as a control, for $6 \mathrm{~h}$ before fixation. With these parameters, no obvious morphological defects could be observed in live treated embryos, in addition to an abnormally curved body shape.

Whole-mount in situ hybridization and immunostaining. We optimized a fluorescence in situ hybridization protocol (Fontaine et al., 2013) for the detection of mRNA in axons, using in vitro transcribed digoxigenin- or fluorescein-labeled probes. Embryos were fixed overnight in 4\% PFA, dehydrated for storage in methanol at $-20^{\circ} \mathrm{C}$, and then rehydrated. When necessary, rehydrated embryos were depigmented in $0.1 \mathrm{M}$ $\mathrm{KOH} / 3 \% \mathrm{H}_{2} \mathrm{O}_{2}$. Probe hybridization and washes were then performed according to standard methods. Immunodetection of the probe was done overnight with anti-digoxigenin or anti-fluorescein peroxidaseconjugated antibodies (Roche), diluted $1 / 100$ or $1 / 200$ in maleate buffer supplemented with $2 \%$ Boehringer Blocking Reagent (Roche). Peroxidase activity was detected with FITC- or Cy3-coupled tyramide $(10 \mu \mathrm{g} /$ $\mathrm{ml}$ ), prepared as described by Davidson and Keller (1999), in the presence of $0.001 \% \mathrm{H}_{2} \mathrm{O}_{2}$. For joint immunodetection of protein, primary antibodies to GFP/Venus (Aves Laboratories, GFP-1020; 1:500) or acetylated-tubulin (Sigma-Aldrich, T-6793; 1:500), were included in the incubation mix. They were detected after the tyramide staining, using appropriate dye-conjugated secondary antibodies: anti-chicken IgY (Jackson Immunoresearch; 1:500), anti-mouse IgG (Molecular Probes; 1:500). mbp (Lyons et al., 2005) and neuroD (Lecaudey et al., 2007) probes were published previously. All probes used are available upon request.

Data analysis. Processed embryos were flat-mounted on microscope slides, then imaged on a Nikon Eclipse E800 epifluorescence microscope or on a Leica Sp5 confocal microscope. For quantifying the transport of each reporter construct, between 11 and 81 transgenic embryos were analyzed and neurons were scored separately for each of the following gross subdivisions of the zebrafish nervous system at the $1.5 \mathrm{~d}$ stage: forebrain, midbrain, hindbrain, spinal cord, and cranial ganglia. We considered only neurons that displayed both venus RNA and myrVenus protein signal in their cell body, and had a clearly myrVenus-labeled process. Each such neuron was assigned to one of three classes. Class 1: no RNA signal outside of the cell body. Class 2: RNA signal present in the axon proximal segment (approximated by measuring one cell diameter along the axon). Class 3: RNA signal present in the axon. We observed the same tendencies in all five categories in terms of axonal localization: neuronal types did not seem to play a biasing role. Therefore, we subsequently merged all scored neurons for a given construct.

\section{Results}

Because no instance of axonal mRNA transport has yet been reported in the zebrafish, we started our study by selecting candidate genes whose mRNA could be detected in axons in at least one of the large-scale screens conducted on rat (Willis et al., 2007; Taylor et al., 2009; Gumy et al., 2011), mouse, and Xenopus (Zivraj et al., 2010) cultured neurons. Among the top-listed genes, we selected nefm, stathmin-like $2 b$, and tubulin $\beta 5$, which have been repeatedly detected in these screens (Table 1) and whose orthologues showed neuronspecific expression profiles in the early zebrafish embryo, ac- 

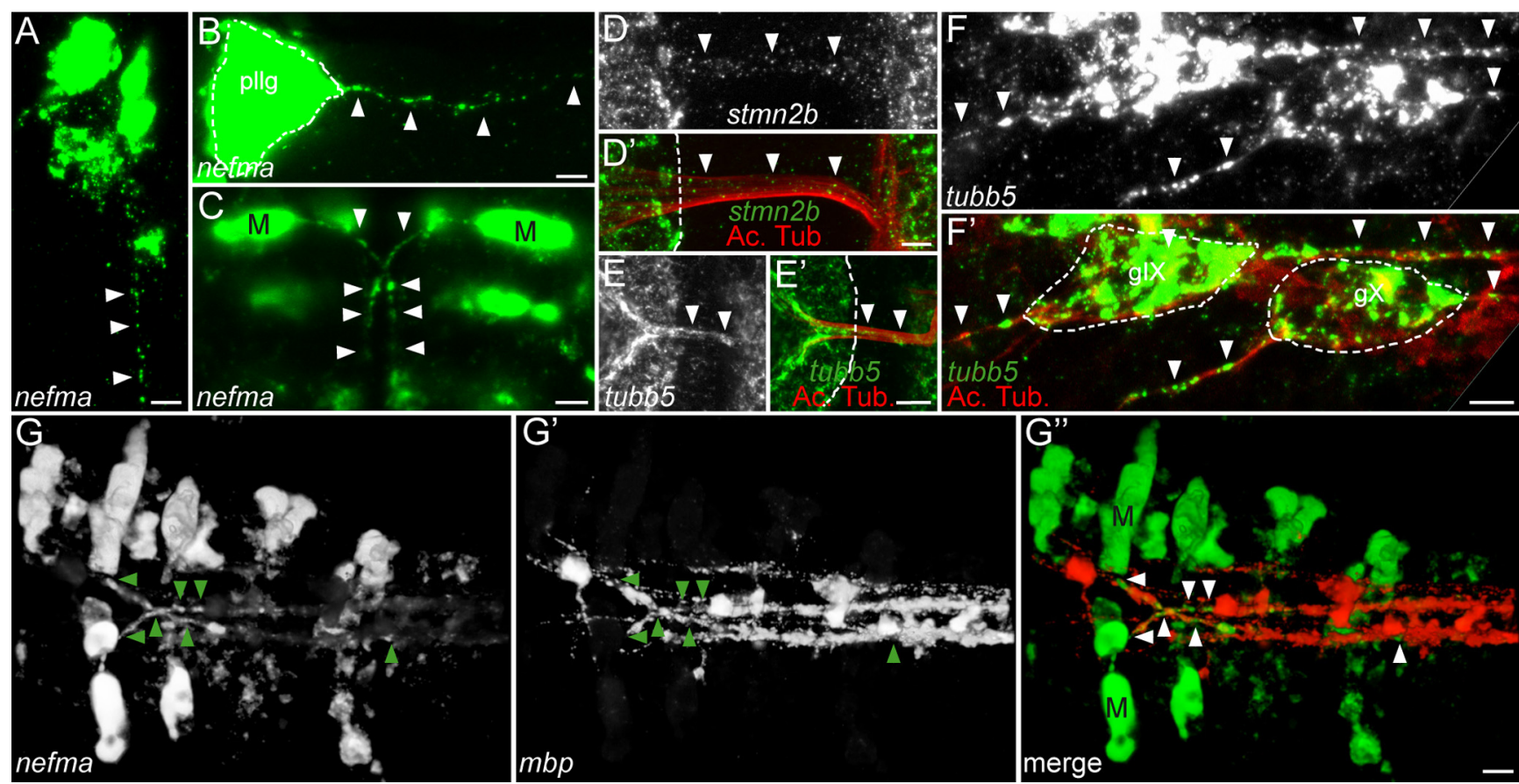

Figure 1. Detection of mRNA in the axons of intact zebrafish embryos. $\boldsymbol{A}-\boldsymbol{F}^{\prime}, \mathrm{mRNA}$ detection (ISH; green or white) with or without axonal staining [acetylated tubulin (Ac. Tub.) immunofluorescence; red] was performed on whole $3 \mathrm{dpf}$ embryos and analyzed by confocal microscopy. $\boldsymbol{A}-\boldsymbol{C}$, nefma mRNA in axons of diencephalic neurons $(\boldsymbol{A})$, of the lateral line nerve $(\boldsymbol{B})$, and of Mauthner reticulospinal neurons $(\boldsymbol{C}) \cdot \boldsymbol{D}, \mathbf{D}^{\prime}$, stmn $2 b \mathrm{mRNA}$ in the optic nerve. $\boldsymbol{E}-\boldsymbol{F}^{\prime}$, tubb5 mRNA in the optic nerve $\boldsymbol{E}, \boldsymbol{E}^{\prime}$ and in several peripheral nerves $\left(\boldsymbol{F}, \boldsymbol{F}^{\prime}\right)$. $\boldsymbol{G}-\boldsymbol{G}^{\prime \prime}$, View of the hindbrain of a $4 \mathrm{dpf}$ embryo, stained by double ISH for nefma (green) and $m b p$ (red) mRNAs. Representation in perspective of a $3 D$ reconstruction of the whole confocal stack with nefma mRNA in white $(\boldsymbol{G})$ or green $\left(\boldsymbol{G}^{\prime \prime}\right)$, $m b p$ mRNA in white $\left(\boldsymbol{G}^{\prime}\right)$ or red $\left(\boldsymbol{G}^{\prime \prime}\right)$. Green or white arrowheads in $\mathbf{G}$ and $\mathbf{G}^{\prime}$ indicate the presence of nefma mRNA where mbp mRNA is not detected. gIX, Glossopharyngeal ganglion; $g X$, vagal ganglion; M, Mauthner cell body; pllg, posterior lateral line ganglion. Arrowheads in $\boldsymbol{A}-\boldsymbol{F}^{\prime}$ indicate mRNAs particles in axons. Scale bars: $\boldsymbol{A}-\boldsymbol{D}^{\prime}, \boldsymbol{F}-\boldsymbol{G}^{\prime \prime}, 10 \mu \mathrm{m} ; \boldsymbol{E}, \boldsymbol{E}^{\prime}, 20 \mu \mathrm{m}$.

Table 2. Summary of reported axonal mRNA

\begin{tabular}{lllll}
\hline & CNS & Optic nerve & Cranial nerves & Posterior lateral line nerve \\
\hline Tubulin beta 5 (tubb5) & Not determined (expression too dense) & +++ & +++ & +++ \\
Neurofilament medium polypeptide (nefma) & +++ (reticul ospinal and diencephalic projections) & Not expressed & +++ & ++ \\
Stathmin like 2b (stmn2b) & Not determined (expression too dense) & + & ++ & ++ \\
\hline
\end{tabular}

For each of the three probed genes, the observed mRNA signals in axons was attributed a qualitative score. +++ Abundant axonal accumulation; ++ clear, but sparser axonal signal; + weak signal.

cording to the Zebrafish Model Organism Database (ZFIN; zfin.org). To test the axonal localization of candidate mRNAs in the whole embryo context, we used sensitive fluorescent in situ hybridization detection combined with immunolabeling of axons.

nefma (neurofilament medium polypeptide a) is a zebrafish orthologue of nefm and encodes a neurofilament intermediate chain. Remarkably, RT-PCR assays have previously indicated the presence of nefm mRNA in the axoplasm of the goldfish Mauthner neuron (Weiner et al., 1996). In zebrafish embryos at the 3 dpf stage, we found nefma mRNA in Mauthner axons (Fig. $1 C$ ), but also in diencephalic axons projecting posteriorly (Fig. $1 A$ ) and in axons forming the posterior lateral line nerve (Fig. $1 B$ ). Although expression of neurofilament-encoding genes is normally restricted to neurons, we wanted to exclude the possibility that the signal we observed could result from expression in oligodendrocytes that wrap around these large caliber axons. We performed simultaneous detection of nefma and $m b p$ mRNAs. As previously described (Lyons et al., 2009), mbp mRNA was readily detected in oligodendrocyte cell bodies as well as in their projections wrapped around the Mauthner axon, but clearly differed from nefma distribution (Fig. $1 G-G^{\prime \prime}$ ). Noticeably, nefma was totally absent from oligodendrocyte cell bodies, ruling out the possibility that the nefma mRNA molecules in the Mauthner axons could originate from glial cells.
In contrast to nefma, stmn $2 b$ (stathmin-like $2 b$, encoding a regulator of microtubule remodeling) and tubb5 (encoding the tubulin $\beta 5$ microtubule subunit) are widely expressed in a large number of neurons. We thus focused our study on isolated nerves, permitting to clearly detect weak RNA axonal labeling without being perturbed by high expression in neighboring cell bodies. stmn $2 b$ and $t u b b 5$ were both expressed in retinal ganglion cells, which project axons to the optic tectum, forming the optic nerve. We found that both mRNAs were present in the optic nerve (Fig. $1 D-E^{\prime}$ ). The weak stmn $2 b$ staining in the retina and the optic nerve prompted us to perform control ISH with a $s t m n 2 b$ sense probe. The resulting signal consisted in even weaker punctate signal scattered throughout the whole tissue (data not shown), suggesting that the larger, more intense dots observed with the antisense probe in the optic nerve did correspond to an actual signal, distinct from ISH background noise. We also visualized tubb5 in peripheral cranial nerves, such as glossopharyngeal and vagal axonal projections (Fig. $1 F, F^{\prime}$ ).

Hence, as summarized in Table 2, several mRNA species display axonal localization in the context of a whole developing vertebrate organism, in both the PNS and CNS.

To determine whether axonal localization in zebrafish embryos resulted from a specific capacity of some mRNA species, as opposed to a generic property of neuronal mRNA, we examined other genes, absent from the list of candidate axonal mRNAs 


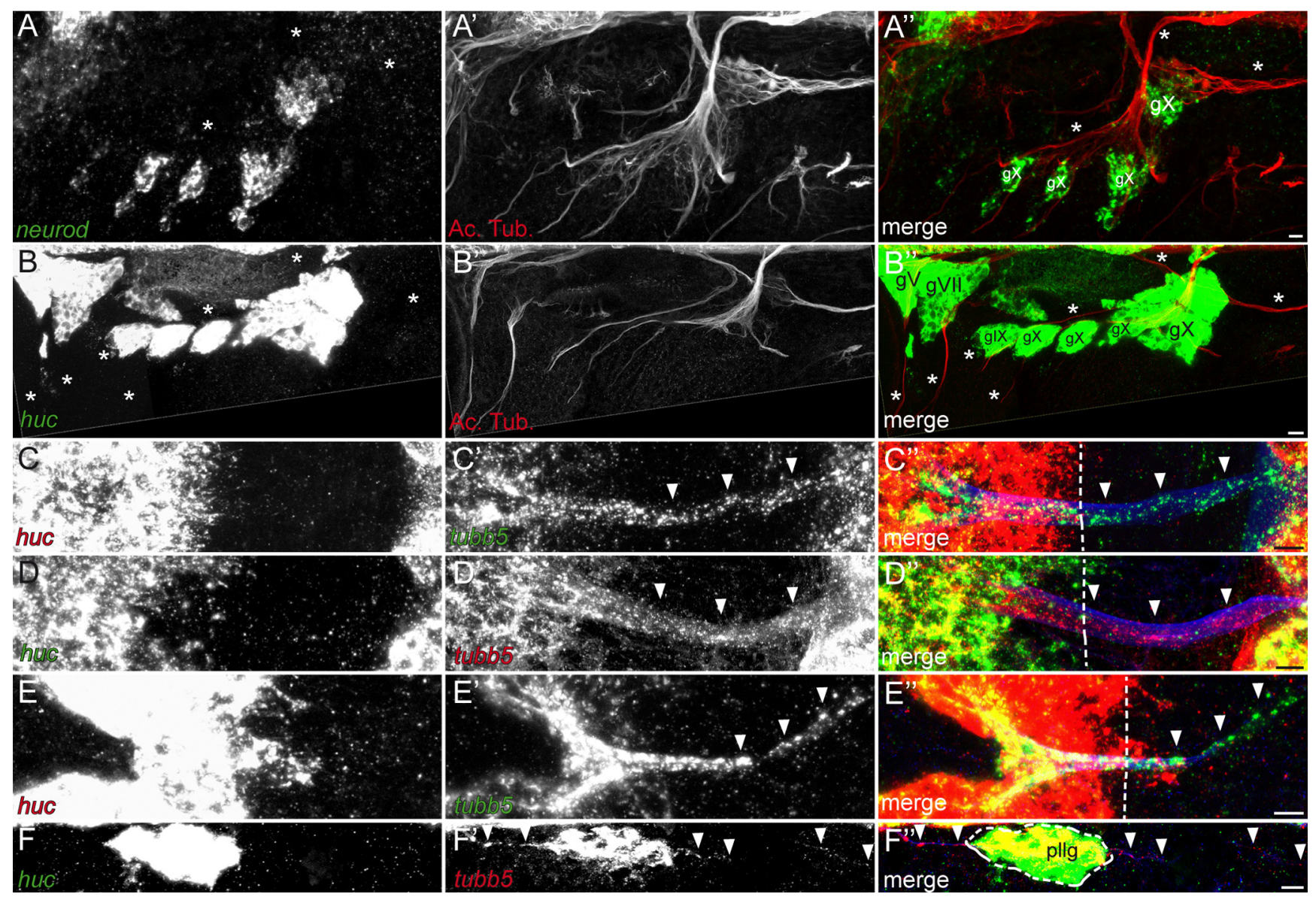

Figure 2. Selective transport of mRNA in axons. $A-B^{\prime \prime}$, Lateral view of cranial nerves of 3 dpfembryos stained by in situ hybridization for neurod $\left(\boldsymbol{A}, A^{\prime \prime}\right)$ or huc $\mathrm{mRNAs}\left(\boldsymbol{B}, \boldsymbol{B}^{\prime \prime}\right)$, combined with axonal marker immunodetection (Ac. Tub; $\boldsymbol{A}^{\prime}, \boldsymbol{A}^{\prime \prime}, \boldsymbol{B}^{\prime}, \boldsymbol{B}^{\prime \prime}$ ) and analyzed by confocal microscopy. $\boldsymbol{A}-\boldsymbol{A}^{\prime \prime}$, neurod mRNA is expressed in posterior part of vagal ganglia. $\boldsymbol{B}-\boldsymbol{B}^{\prime \prime}$, huc $\mathrm{mRNA}$ is expressed in trigeminal, facial, glossopharyngeal and middle part of vagal ganglia. Both mRNAs are excluded from cranial nerves. White asterisks indicate the absence of mRNA detection in the nerves. $\mathbf{C}-\boldsymbol{F}^{\prime}$, Double ISH for tubb5 and huc mRNAs combined with axonal marker immunodetection (acetylated tubulin; blue). Staining is shown in RGCs and optic nerve at $3.5 \mathrm{dpf}\left(\boldsymbol{C}-\boldsymbol{D}^{\prime \prime}\right)$ and at $1.5 \mathrm{dpf}\left(\boldsymbol{E}-\boldsymbol{E}^{\prime \prime}\right)$, and in the lateral line ganglion and nerve at $1.5 \mathrm{dpf}\left(\boldsymbol{F}-\boldsymbol{F}^{\prime \prime}\right)$. In $\boldsymbol{C}_{-\boldsymbol{C}^{\prime \prime}}$ and $\boldsymbol{E}-\boldsymbol{E}^{\prime \prime}$, huc $\mathrm{mRNA}$, detected with tyramide-Cy3, is shown in red and tubb5 mRNA, detected with tyramide-FITC, is shown in green. In $\boldsymbol{D}-\boldsymbol{D}^{\prime \prime}$ and $\boldsymbol{F}-\boldsymbol{F}^{\prime \prime}$, huc mRNA, detected with tyramide-FITC, is shown in green and tubb5 mRNA, detected with tyramide-Cy3, is shown in red. Arrowheads indicate mRNA particles in axons. gV, Trigeminal ganglion; gVII, facial ganglion; glX, glossopharyngeal ganglion; $\mathrm{gX}$, vagal ganglion. Scale bars, $10 \mu \mathrm{m}$.

collated from large-scale studies (Table 1). We selected the neuronal markers neurod and huc/elavl3 because they are highly expressed in most types of neurons. Although high amounts of neurod (Fig. 2A-A") and huc (Fig. $2 B-B^{\prime \prime}$ ) mRNA were present in several cranial ganglia, we never observed them in the corresponding cranial nerves (Fig. $2 A-B^{\prime \prime}$ ), demonstrating their exclusion from the axonal compartment. To confirm this observation, we compared the subcellular localization of huc and tubb5 mRNAs expressed in the same neurons. At $3.5 \mathrm{dpf}$, retinal ganglion cells (RGCs) expressed both transcripts (Fig. $2 C-D^{\prime \prime}$ ), but only tubb5 mRNA was observed in the optic nerve formed by RGC axonal projections (Fig. $2 C^{\prime}, D^{\prime}$ ), whereas huc mRNA was restricted to the RGC cell bodies (Fig. 2C,D). The differential axonal localization of those two mRNAs was already observed at $1.5 \mathrm{dpf}$ (Fig. 2E-E'). Both genes were also highly expressed in the posterior lateral line (pll) ganglion at $1.5 \mathrm{dpf}$ (Fig. $\left.2 F-F^{\prime \prime}\right)$. tubb5 mRNA could readily be observed in the projecting pll nerve (Fig. $2 F^{\prime}$ ), whereas $h u c$ was never detected in this nerve (Fig. $2 F$ ). Thus, our results indicate that only specific mRNA species localize to axons, whereas others are retained in the cell body.

To test the dependence of this mRNA axonal localization on microtubule integrity, we analyzed tubb5 mRNA localization in the pll nerve of embryos treated with the microtubule polymer- ization inhibitor nocodazole (Butler et al., 2010). We found a severe reduction of the proximal RNA labeling in nocodazoletreated embryos (Fig. $3 C-C^{\prime \prime}$ ) compared with DMSO-treated (Fig. $3 B-B^{\prime \prime}$ ) or control (Fig. $3 A-A^{\prime \prime}$ ) embryos. Distal RNA labeling was less affected, which may be explained if it corresponds to molecules that had already been sent to the axonal compartment at the time of nocodazole treatment. Scoring multiple embryos showed that although 11/11 control and 7/10 DMSO-treated embryos had detectable tubb5 mRNA all along the length of the pll nerve, the proportion dropped to 2/9 in embryos treated with 0.5 $\mu \mathrm{M}$ nocodazole, and $0 / 10$ for embryos treated with $1 \mu \mathrm{M}$ nocodazole, indicating a dose-dependent effect. Therefore, this axonal mRNA localization requires microtubule integrity, suggesting that it reflects selective transport along the axon.

Next, we designed a reporter system aimed at investigating the mechanisms of in vivo axonal mRNA localization. Previous studies have emphasized the role of the $3^{\prime} \mathrm{UTR}$ in mRNA transport mechanisms. We grafted candidate $3^{\prime}$ UTRs next to the coding sequence of a membrane-bound fluorescent protein (myristoylated Venus), placed under the control of a minimal promoter linked to 5 UAS sites (Fig. 4A). An exclusively neuronal, mosaic expression of the reporter was obtained by injecting the DNA construct into the eggs of stable transgenic embryos expressing 


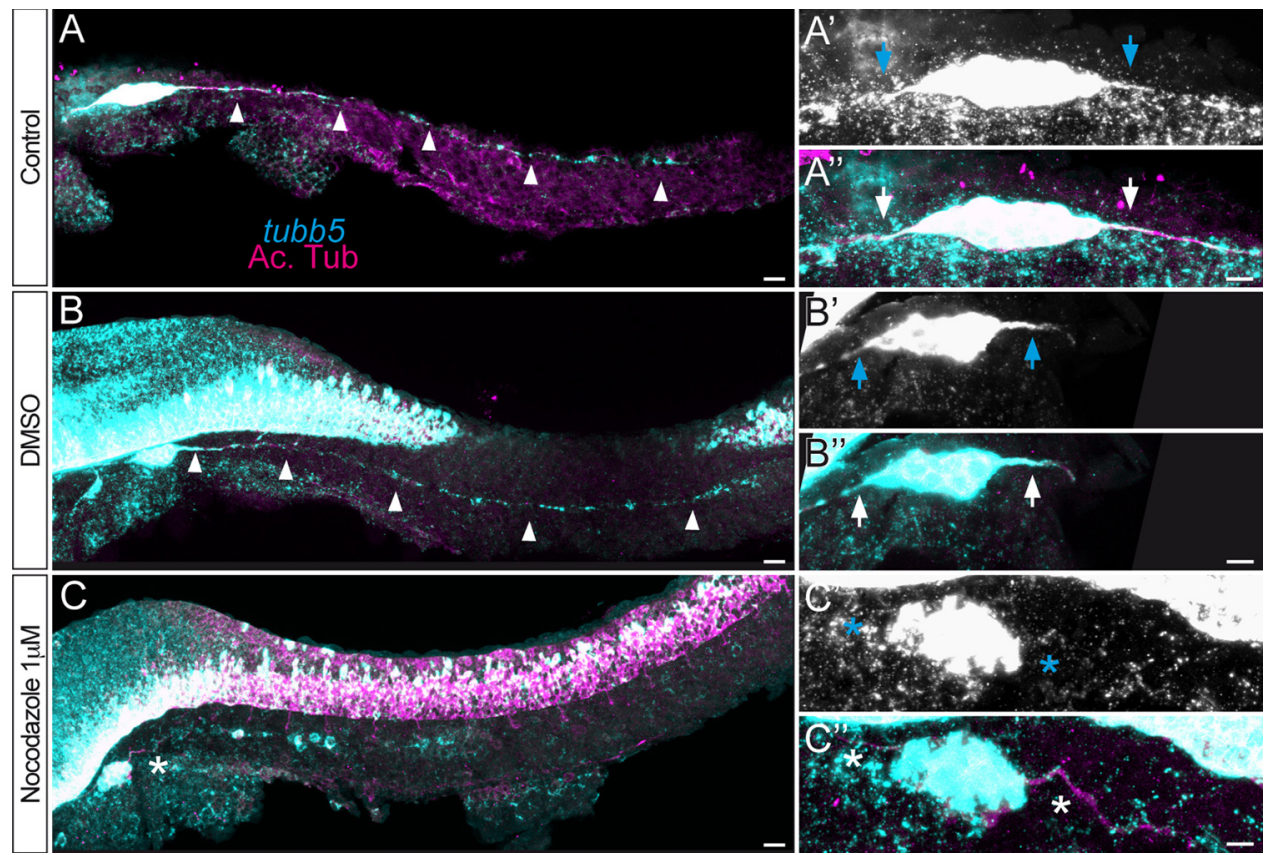

Figure 3. Microtubule depolymerization by nocodazole perturbs axonal mRNA transport. $A-C^{\prime \prime}$, Representative view of the lateral line nerve from embryos at $32 \mathrm{hpf}$, stained by ISH for tubb5 mRNA (cyan), combined with immunofluorescence against acetylated tubulin (magenta) to visualize the nerve projection. Embryos were either not treated $\left(\boldsymbol{A}-\boldsymbol{A}^{\prime \prime}\right)$, or treated with DMSO $\left(\boldsymbol{B}-\boldsymbol{B}^{\prime \prime}\right)$ or with $1 \mu$ m nocodazole in DMSO $\left(\boldsymbol{C}-C^{\prime \prime}\right)$ for $6 \mathrm{~h}$ before analysis. $A-C$, Low-magnification views of the lateral line ganglion and nerves. $\boldsymbol{A}^{\prime}, \boldsymbol{A}^{\prime \prime}, \boldsymbol{B}^{\prime}, \boldsymbol{B}^{\prime \prime}, \boldsymbol{C}^{\prime}, \boldsymbol{C}^{\prime \prime}$, High-magnification views showing the posterior lateral line ganglion and its two neuronal projections. tubb5 mRNA particles in distal (arrowheads) and proximal (arrows) neuronal projections are indicated. White asterisks indicate an absence of tubb5 mRNA detection in the proximal part of neuronal projections. Scale bars: $\boldsymbol{A}-\boldsymbol{C}, 20 \mu \mathrm{m} ; \boldsymbol{A}^{\prime}, \boldsymbol{A}^{\prime \prime}, \boldsymbol{B}^{\prime}, \boldsymbol{B}^{\prime \prime}, \boldsymbol{C}^{\prime}, \boldsymbol{C}^{\prime \prime}, 10 \mu \mathrm{m}$. Persistence of acetylated tubulin staining after nocodazole treatment under these parameters is normal and expected, as previously observed by Butler et al. (2010). Note however the twisted shape of the pll nerve upon nocodazole treatment $\left(\boldsymbol{C}^{\prime \prime}\right)$, presumably consecutive to a weakening of the microtubule backbone.

Gal4 under the control of the neuronal $h u C$ promoter (elavl3: Gal4; Akerboom et al., 2012). At 1.5 dpf, we visualized the reporter mRNA using a venus antisense RNA probe, together with the axonal projection of the reporter-expressing neurons using an anti-Venus antibody. This standardized design and common antisense probe for all constructs allowed us to reliably compare results among different experiments.

When expressed in isolated neurons, both the tubb5 3'UTR and the nefma $3^{\prime}$ UTR reporter RNAs were readily detected all along the axon, with frequent accumulation at the growth cone (Fig. $\left.4 B, B^{\prime}, D, D^{\prime}\right)$. For each construct, we scored isolated neurons expressing the reporter mRNA according to three distinct labeling patterns (Fig. $4 L$; see Material and Methods): negative (RNA restricted to the cell body), proximal (labeling restricted to an initial 1-cell-diameter long axonal segment) or positive (RNA in distal part of axon). Quantification showed that $81 \%$ of the neurons expressing the tubb5 $3^{\prime}$ UTR reporter and $53 \%$ of the neurons expressing the nefma $3^{\prime}$ UTR reporter, exhibited mRNApositive axons (Fig. $4 L$ ). We then tested in similar conditions the $3^{\prime}$ UTRs of the huc and neurod mRNAs, which are not endogenously detected in axonal projections (Fig. $4 C, C^{\prime}, E, E^{\prime}$ ). huc and neurod 3'UTR reporters were consistently restricted to the cell bodies and proximal axons in $89 \%$ and $64 \%$ of expressing neurons, respectively (Fig. $4 L$ ). These results largely recapitulated the axonal localization patterns of the corresponding endogenous mRNAs, indicating that their $3^{\prime}$ UTR contains important localization signals. Whereas tubb5 and huc $3^{\prime}$ UTRs drive most efficiently reporter RNA respectively in or out of axons, nefma and neurod 3'UTRs seem to display more variable behavior in different neurons, suggesting that additional localization signals may reside outside $3^{\prime}$ UTR sequences, similar to what has been reported for synaptic targeting of mRNA (Meer et al., 2012). How- ever, when we coexpressed myr-mCherry-nefma together with myr-Venus-neurod in the same neurons and directly compared their distribution by two-color ISH, the reporter mRNA containing nefma 3'UTR was always found further away from the cell body than the reporter containing neurod $3^{\prime} \mathrm{UTR}$ (Fig. $4 M-M^{\prime \prime \prime}$ ). Thus, by constitutively driving the expression of equivalent amounts of reporter constructs in the same neurons, our system allows to distinguish between sequences that are more or less efficient to drive axonal localization, and provides an estimate of the propensity of any $3^{\prime}$ UTR sequence to trigger transport.

Directly assessing the distribution of endogenous ubiquitely expressed transcripts is not possible, due to signal in neighboring tissues masking that of axonal RNA. Nevertheless, the reporter system allowed to test the transport of ubiquitously expressed mRNA, such as the two zebrafish $\beta$-actin genes (actb1 and actb2), whose chicken orthologues were previously reported as transported in axons (Bassell et al., 1998). actb1 and actb2 3'UTR reporters were found in a large proportion (respectively $87 \%$ and 94\%) of axons (Fig. $4 F-G^{\prime}, L$ ). Therefore, both zebrafish $\beta$-actin genes have retained the ability to be transported to axons. Our reporter system also allows testing RNA sequences from others species. Thus, the well characterized $3^{\prime} \mathrm{UTR}$ of the chicken $\beta$-actin gene, a canonical axonally localized mRNA (Zhang et al., 2001), resulted in axonal localization of the reporter mRNA in $84 \%$ of reporter-expressing neurons (Fig. $4 H, H^{\prime}, L$ ). In contrast, when we used a truncated version of the chicken $\beta$-actin $3^{\prime} \mathrm{UTR}$ without the localization zipcode (Kislauskis et al., 1994), mRNA labeling within axons accordingly dropped to $19 \%$ of the reporter-expressing neurons (Fig. 4I, I',L). Similarly, mouse $\beta$-actin and $\gamma$-actin $3^{\prime}$ UTRs displayed opposite behaviors in the reporter assay (Fig. $4 J-K^{\prime}$ ), consistent with their contrasted localization profiles in neuronal cultures (Bassell et al., 1998): 80\% of 


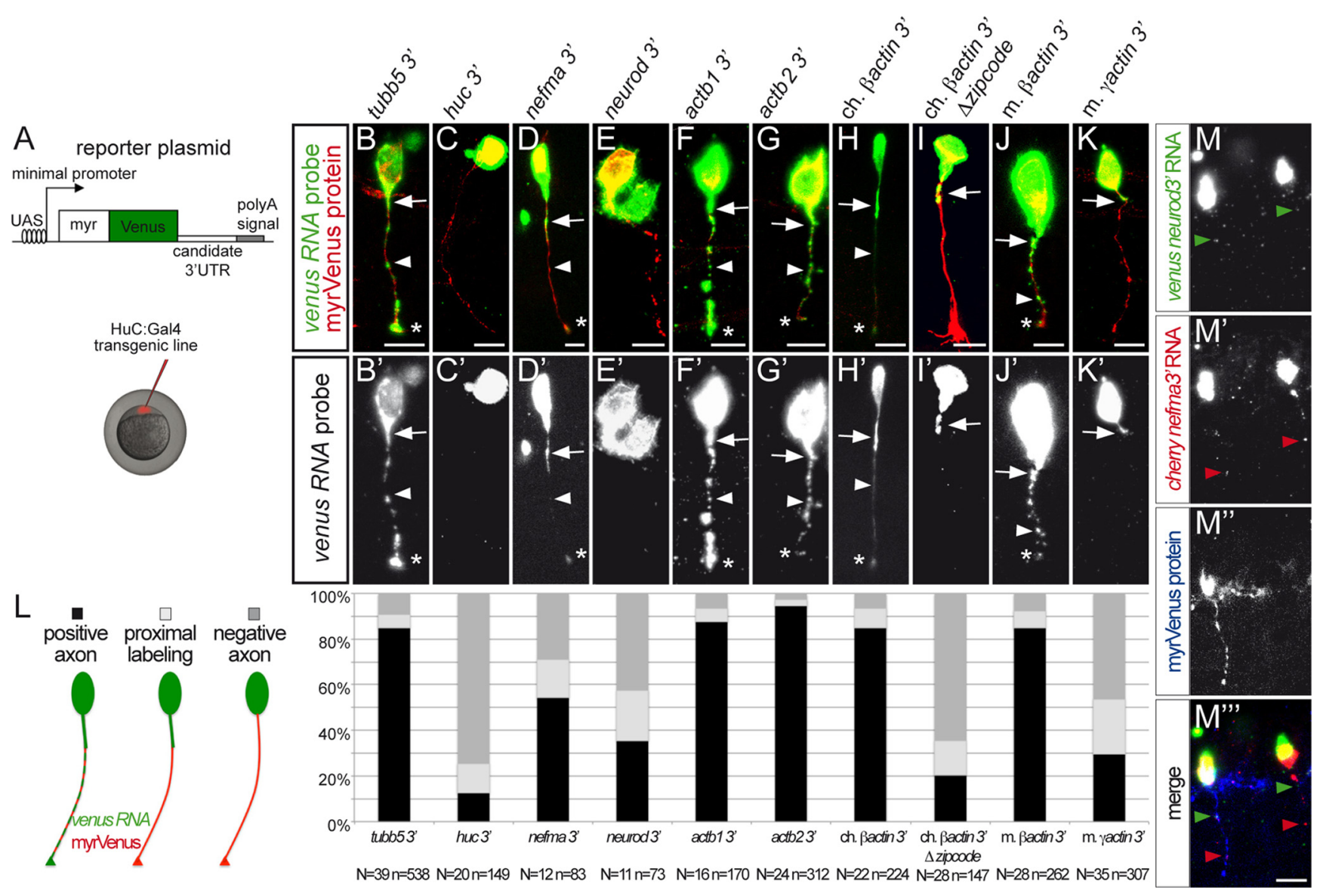

Figure 4. Reporter system of axonal mRNA transport in zebrafish embryos. $A$, Schematic view of the reporter system. A candidate 3'UTR was fused to the coding sequence of a membrane-bound form of the Venus fluorescent protein (myr-Venus), placed under the control of a minimal promoter linked to UAS sites. The reporter construct was injected into 1 cell-stage embryos of the HuC:Gal4 transgenic line. $\left(\boldsymbol{B}-\boldsymbol{K}^{\prime}\right)$ Representative neurons: forebrain $(\boldsymbol{C})$, hindbrain $(\boldsymbol{D}, \boldsymbol{F}, \boldsymbol{H}, \boldsymbol{I})$, spinal chord $(\boldsymbol{B}, \boldsymbol{E}, \boldsymbol{G}, \boldsymbol{J}, \boldsymbol{K})$ neurons from embryos injected with reporter constructs containing the $3^{\prime} \mathbf{U T R}$ indicated above each panel, and analyzed at $1.5 \mathrm{dpf}$ by ISH. Reporter mRNA, shown in green $(\boldsymbol{B}-\boldsymbol{K})$ or white $\left(\boldsymbol{B}^{\prime}-\boldsymbol{K}^{\prime}\right)$, was detected using an antisense venus probe, followed by immunolabeling of myr-Venus-expressing neurons in red. Arrows indicate proximal accumulation of reporter RNAs. Arrowheads indicate RNA particles detected in axons. Asterisks indicate reporter RNA accumulation in growth cones. L, Quantitative analysis of RNA reporter axonal localization, according to three classes: negative axon (reporter RNA only in cell body), proximal labeling (reporter RNA limited to a one-cell-diameter distance from the cell body), and positive axon. ( $\left.\boldsymbol{M}-\boldsymbol{M}^{\prime \prime \prime}\right)$ Representative spinal chord neurons from embryos coinjected with two reporter constructs, venus neurod $3^{\prime} U T R$ and mcherry nefma 3'UTR, and analyzed at $1.5 \mathrm{dpf}$ by double ISH using venus and cherry RNA probes, followed by myrVenus immunodetection. venus neurod $3^{\prime}$ UTR RNA detected with venus probe (green), cherry nefma 3' UTR RNA detected with cherry probe (red) and axonal projection labeled with Venus antibody (blue). Green arrowheads indicate the most distal venus neurod $3^{\prime}$ UTR RNA particle detected in axons. Red arrowheads indicate the most distal cherry nefma $3^{\prime} U T R R$ RNA particle detected in axons. ch, Chicken; $\Delta$, deletion; $m$, mouse; $N$, number of scored embryos; $n$, number of scored neurons. Scale bars, $10 \mu \mathrm{m}$.

mouse $\beta$-actin $3^{\prime} \mathrm{UTR}$ reporter-expressing neurons had positive axons, whereas the score dropped to $28 \%$ with mouse $\gamma$-actin 3'UTR (Fig. 4L). Together, these results suggest that the mechanisms governing mRNA transport are conserved among vertebrate species.

We took advantage of the reporter system to determine which specific motifs in the tubb5 3'UTR were important for axonal transport. To this end, we divided the tubb5 $3^{\prime} \mathrm{UTR}$ into four fragments and tested each of them in the reporter system (Fig. $5 A$ ). We found that only fragment 223-453 (Fig. 5D) behaved similarly to the whole tubb5 3'UTR (Fig. 5C): $71 \%$ of reporterexpressing neurons showed axonal localization of the reporter RNA compared with $81 \%$ with the whole tubb5 $3^{\prime}$ UTR (Fig. $5 B$ ). In contrast, for the three remaining fragments (1-223, 453-683, and 683-911) only 13,21, and 18\%, respectively, of reporterexpressing neurons displayed axonal localization (Fig. $5 B, E, F$ ). Conversely, the deletion of fragment 223-453 in the tubb5 $3^{\prime}$ UTR led to a marked reduction in the proportion of neurons with axonal mRNA localization (Fig. $5 B$ ). These results thus show that fragment 223-453 is both necessary for axonal transport driven by the tubb5 3'UTR and sufficient to drive axonal localization of reporter mRNA in neurons of the zebrafish embryo.

Finally, we split fragment 223-453 into several overlapping subfragments (Fig. 5G) and studied their activity using the reporter system. Whereas fragment 223-376 was inefficient in driving axonal localization of the reporter (Fig. $5 \mathrm{H}$ ), both fragments $336-412$ and $376-453$ recapitulated the effect observed with fragment $223-453$, with $71 \%$ of neurons showing positive axonal localization of reporter RNA (Fig. $5 H$ ). This strongly suggests that the 37-nucleotide sequence between positions 376-412 contains a motif of prime importance for axonal transport. To confirm this, the reporter construct was narrowed down to the putative zipcode (fragment 376-412), and scored for axonal localization. The resulting profile showed that the 37-nucleotide fragment is sufficient to induce substantial transport (59\% positive axons; Fig. $5 H$ ), albeit less robustly than either of the larger fragments comprising it.

Together, the above results highlight the role of a novel zipcode RNA motif, contained in a 37-nucleotide sequence of $t u b b 5$ 3'UTR, for axonal mRNA localization in the developing zebrafish 

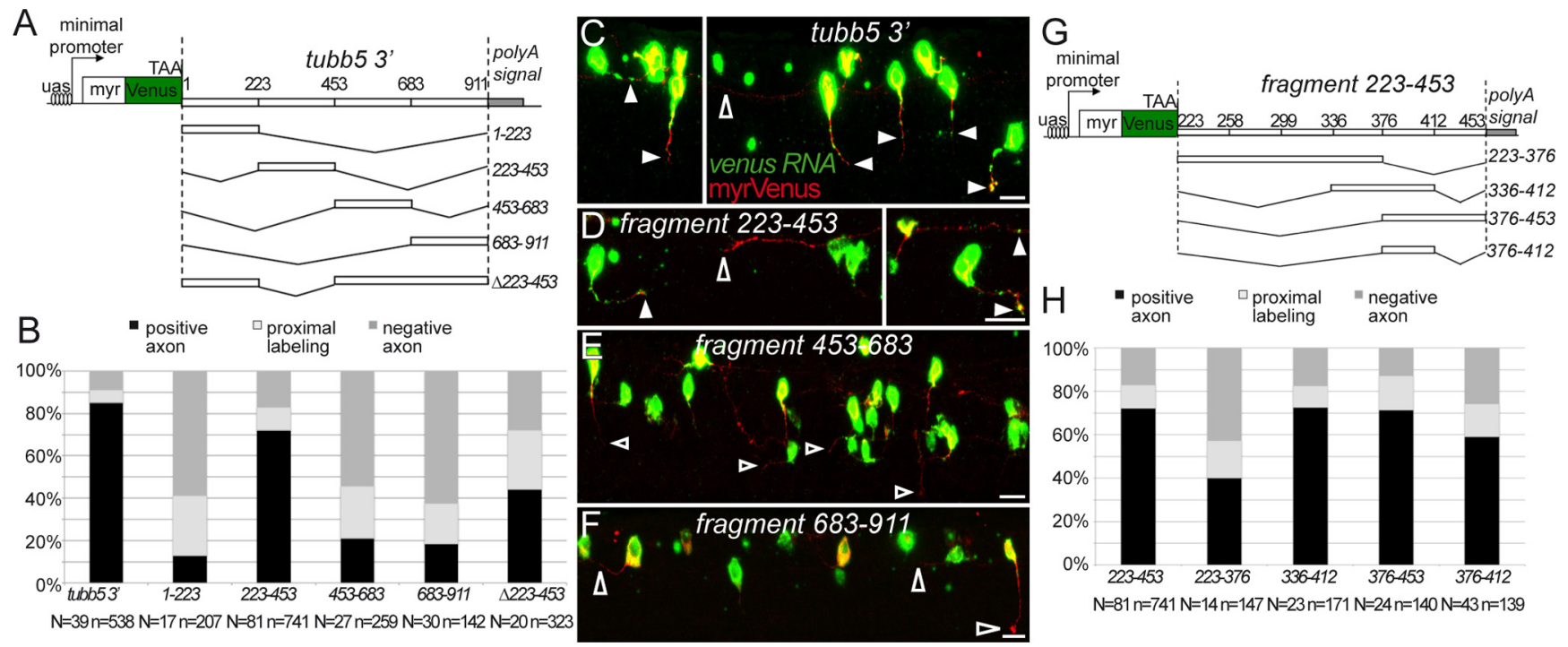

Figure 5. Identification of a RNA motif responsible for tubb5 mRNA transport in axons. A, Schematic view of the reporters containing fragments of the tubb5 $3^{\prime} U$ UTR. All constructs end with the same polyadenylation signal sequence. $\boldsymbol{B}$, Quantitative analysis of axonal localization of the reporter RNAs shown in $\boldsymbol{A}$, according to the three classes defined in Figure $4 L$. $\boldsymbol{C}-\boldsymbol{F}$, Representative pictures of axonal localization of RNA reporter containing the whole tubb5 3'UTR (C), or fragments 223-453 (D), 453-683 (E), or 683-911 (F); axon in red and RNA reporter in green. $\boldsymbol{G}$, Schematic view of reporters containing subfragments of fragment 223-453. $\boldsymbol{H}$, Quantitative analysis of axonal localization of reporter RNAs shown in G. Filled white arrowheads indicate reporter RNA in axons, empty arrowheads indicate axons where reporter RNA was absent. N, number of scored embryos; n, number of scored neurons. Scale bars, $20 \mu \mathrm{m}$.

embryo, but also suggest that modulation by the folding context, or the cooperation of several minor additional motifs, are required to achieve full efficiency of transport.

\section{Discussion}

Subcellular localization of messenger RNA is increasingly acknowledged as a widespread phenomenon; for example, $\sim 70 \%$ of transcripts in early Drosophila embryos exhibit specific subcellular distributions (Lécuyer et al., 2007). In neurons, selective transport and regulated local translation of mRNA have been invoked as a mechanism underlying axon guidance, growth cone homeostasis, and intra-axonal signaling (for review, Jung et al., 2012). Yet, little direct evidence of specific axonal mRNA transport in vivo exists in the literature. Because observing mRNA in situ generally involves labor-intensive techniques, observations have often focused on local detection of mRNA protein product as a proxy for mRNA transport (Bassell et al., 1998), raising the question whether the differences observed between transported (e.g., $\beta$-actin) and nontransported (e.g., $\gamma$-actin) mRNA represent genuine indications of mRNA transport rather than, e.g., differential regulation of translation of the corresponding mRNA. Moreover, because almost all research on axonal mRNA has involved dissociating neurons, or dissecting explants, before letting them regrow axons in culture, it has been argued that mRNA transport and local protein synthesis observed in such conditions may represent a trauma-induced, regenerationspecific phenomenon, bearing limited relevance to the growth of axons in their normal environment. This view is substantiated by a controversy over what biological functions of the axons really depend on the local synthesis of protein (Roche et al., 2009; Cheever et al., 2011; Nédelec et al., 2012).

Building upon the large body of knowledge generated by previous work on cultured neurons, particularly transcriptomics studies aimed at characterizing the full complement of axonal mRNA (Willis et al., 2007; Taylor et al., 2009; Andreassi et al., 2010; Gumy et al., 2011; Zivraj et al., 2010), our findings provide, for the first time, evidence that mRNAs are transported to devel- oping axons in the zebrafish embryo, a leading model organism for studying early development of the vertebrate nervous system. The axonal mRNA we observe shares several important features with what has been described in culture systems, such as accumulation at the growth cone, signal carried by the $3^{\prime} \mathrm{UTR}$, dependence on microtubule integrity, and transport of $\beta$-actin mRNA. Furthermore, by recapitulating this in vivo axonal transport in a reporter system, we show that it stems from a specific property of certain sequences, independent on mRNA expression levels. Finally, we identify a novel RNA zipcode motif responsible for the axonal transport of $t u b b 5$ mRNA.

The development of a reporter system assay, in addition to confirming endogenous localization patterns, brings additional insight in several aspects.

First, although it has been suggested that mRNA occasionally detected in axons in vivo could result from glia-to-axon transfer (for review, Alvarez et al., 2000), this possibility is ruled out in our experiments, because only neurons express the reporter construct. This is confirmed, in the case of endogenously expressed nefma, by the fact that nefma mRNA is not detected in oligodendrocytes.

Second, the reporter system we devised allows to assay the transport of mRNA molecules which could not be observed otherwise, including that of ubiquitously expressed genes ( $\beta$-actin) or of mRNA from heterologous species. In addition to supporting the evolutionary conservation of axonal mRNA transport mechanisms, the latter is of particular interest in that it will render possible to test, in the zebrafish embryo, hypotheses related to the axonal transport of any vertebrate mRNA, including those possibly linked to human pathologies (Dahm and Macchi, 2007), such as spinal muscular atrophy (Akten et al., 2011).

Finally, it allowed us to dissect the sequence of one transported 3'UTR (tubb5) so as to delineate a signal sequence (zipcode) required to trigger axonal localization. Such signal sequences are remarkably sparse in the literature. The canonical example consists in two regions of the chicken $\beta$-actin mRNA, 
which need to be deleted to abolish transport in fibroblasts (Kislauskis et al., 1994), or masked by antisense oligonucleotides to prevent $\beta$-actin localization in axons (Zhang et al., 2001). Elucidation of the structure of the Imp1 C-terminal RNA-binding domain bound to its target (Chao et al., 2010) has led to the definition of a consensus binding sequence, representing a candidate "signature" found in several mRNA species, at least one of which is effectively transported to neuronal processes in culture (Patel et al., 2012). However, the lack of primary sequence motif similarity among known transported mRNA molecules, together with the fact that Imp1-targeted RNA-immunoprecipitation experiments failed to detect significant amounts of Imp 1 associated with $\beta$-actin mRNA in living cells (Hafner et al., 2010), suggest that the Imp1-zipcode interaction model may explain only a marginal portion of axonal mRNA transport. The newly identified tubb5 zipcode identified in the present work is not only necessary, but also sufficient, for axonal localization. Examination of the zipcode sequence reveals that it is $\mathrm{G} / \mathrm{U}$ rich and does not contain any of the proposed consensus motifs suggested to mediate binding of Imp1 to its cognate targets (Jønson et al., 2007; Hafner et al., 2010; Patel et al., 2012), implying that it is of a novel kind. However, the function of the $t u b b 5$ zipcode may ultimately depend on its secondary/tertiary structure upon folding, precluding comparison with known motifs: such cases have been described for RNA cis-elements in the Drosophila syncytial blastoderm (Bullock et al., 2010), as well as in Aplysia neurites (Meer et al., 2012). Comparison of multiple zipcodes should ultimately help understanding how these signals are interpreted by the cell machinery.

In principle, the detection of mRNA in axons could indirectly result from differences in transcript stability or copy number among different genes. Even though we intentionally selected highly expressed genes (huc, neurod) when searching for nonaxonal transcripts, we cannot formally exclude this possibility for endogenous transcripts because comparing molecule abundance based solely on the intensity of hybridization signals may be biased when using different hybridization probes. In contrast, for comparison among reporter constructs, the use of a common antisense probe allowed evaluation of the global amount of mRNA produced, which was similar for all constructs. It is still possible however that accumulation in axons could result from passive diffusion followed by selective degradation or stabilization specifically in the axonal compartment. Although this could not be tested directly, the fact that axonal mRNA depend on the integrity of microtubules rather argues in favor of a direct transport mechanism.

It is intriguing to note that most our reporter constructs show some degree of axonal localization, with variable extent ranging from very low (such as huc) to very high (such as tubb5). This suggests that the propensity of being transported to axons is, rather than a discrete binary property, a continuous variable, which our system can measure. This has profound implications on the logics underlying mRNA axonal transport, implying that it may not rely on a single all-or-nothing binary determinant, but on the integration of several, potentially positive and negative, signals carried by the $3^{\prime}$ UTR. This property might explain why studies of the axonal transcriptome show limited overlap in their results: the highest scoring mRNA in one condition can be undetected in another (Table 1). The multidetermined nature of axonal localization signals could reconcile this discrepancy if, for example, some signals prevail in certain types of neurons or conditions, whereas different ones do in other cases, making the axonal transcriptome a pool of somewhat variable composition. Further experiments will be needed to confirm this theory.

Overall, our results indicate that axonal transport of mRNA is an important feature of normal development, arguing for further investigation into the regulation and function of axonal protein synthesis in the coordinated growth of axons that forms a whole nervous system. The tools developed in the zebrafish embryo should provide means of getting further insight into these processes.

\section{References}

Akerboom J, Chen TW, Wardill TJ, Tian L, Marvin JS, Mutlu S, Calderón NC, Esposti F, Borghuis BG, Sun XR, Gordus A, Orger MB, Portugues R, Engert F, Macklin JJ, Filosa A, Aggarwal A, Kerr RA, Takagi R, Kracun S, et al. (2012) Optimization of a GCaMP calcium indicator for neural activity imaging. J Neurosci 32:13819-13840. CrossRef Medline

Akten B, Kye MJ, Hao le T, Wertz MH, Singh S, Nie D, Huang J, Merianda TT, Twiss JL, Beattie CE, Steen JA, Sahin M (2011) Interaction of survival of motor neuron (SMN) and $\mathrm{HuD}$ proteins with mRNA cpg15 rescues motor neuron axonal deficits. Proc Natl Acad Sci U S A 108:10337-10342. CrossRef Medline

Alvarez J, Giuditta A, Koenig E (2000) Protein synthesis in axons and terminals: significance for maintenance, plasticity and regulation of phenotype: with a critique of slow transport theory. Prog Neurobiol 62:1-62. CrossRef Medline

Andreassi C, Zimmermann C, Mitter R, Fusco S, De Vita S, Saiardi A, Riccio A (2010) An NGF-responsive element targets myo-inositol monophosphatase-1 mRNA to sympathetic neuron axons. Nat Neurosci 13: 291-301. CrossRef Medline

Bassell GJ, Singer RH, Kosik KS (1994) Association of poly(A) mRNA with microtubules in cultured neurons. Neuron 12:571-582. CrossRef Medline

Bassell GJ, Zhang H, Byrd AL, Femino AM, Singer RH, Taneja KL, Lifshitz LM, Herman IM, Kosik KS (1998) Sorting of beta-actin mRNA and protein to neurites and growth cones in culture. J Neurosci 18:251-265. Medline

Bullock SL, Ringel I, Ish-Horowicz D, Lukavsky PJ (2010) A'-form RNA helices are required for cytoplasmic mRNA transport in Drosophila. Nat Struct Mol Biol 17:703-709. CrossRef Medline

Butler R, Wood JD, Landers JA, Cunliffe VT (2010) Genetic and chemical modulation of spastin-dependent axon outgrowth in zebrafish embryos indicates a role for impaired microtubule dynamics in hereditary spastic paraplegia. Dis Model Mech 3:743-751. CrossRef Medline

Campbell DS, Holt CE (2001) Chemotropic responses of retinal growth cones mediated by rapid local protein synthesis and degradation. Neuron 32:1013-1026. CrossRef Medline

Chao JA, Patskovsky Y, Patel V, Levy M, Almo SC, Singer RH (2010) ZBP1 recognition of beta-actin zipcode induces RNA looping. Genes Dev 24: 148-158. CrossRef Medline

Cheever TR, Olson EA, Ervasti JM (2011) Axonal regeneration and neuronal function are preserved in motor neurons lacking $\beta$-actin in vivo. PLoS ONE 6:e17768. CrossRef Medline

Collins RT, Linker C, Lewis J (2010) MAZe: a tool for mosaic analysis of gene function in zebrafish. Nat Methods 7:219-223. CrossRef Medline

Cox LJ, Hengst U, Gurskaya NG, Lukyanov KA, Jaffrey SR (2008) Intraaxonal translation and retrograde trafficking of CREB promotes neuronal survival. Nat Cell Biol 10:149-159. CrossRef Medline

Dahm R, Macchi P (2007) Human pathologies associated with defective RNA transport and localization in the nervous system. Biol Cell 99:649661. CrossRef Medline

Davidson LA, Keller RE (1999) Neural tube closure in Xenopus laevis involves medial migration, directed protrusive activity, cell intercalation and convergent extension. Development 126:4547-4556. Medline

Fontaine R, Affaticati P, Yamamoto K, Jolly C, Bureau C, Baloche S, Gonnet F, Vernier P, Dufour S, Pasqualini C (2013) Dopamine inhibits reproduction in female zebrafish (Danio rerio) via three pituitary D2 receptor subtypes. Endocrinology 154:807-818. CrossRef Medline

Glinka M, Herrmann T, Funk N, Havlicek S, Rossoll W, Winkler C, Sendtner M (2010) The heterogeneous nuclear ribonucleoprotein- $\mathrm{R}$ is necessary for axonal beta-actin mRNA translocation in spinal motor neurons. Hum Mol Genet 19:1951-1966. CrossRef Medline 
Gumy LF, Yeo GS, Tung YC, Zivraj KH, Willis D, Coppola G, Lam BY, Twiss JL, Holt CE, Fawcett JW (2011) Transcriptome analysis of embryonic and adult sensory axons reveals changes in mRNA repertoire localization. RNA 17:85-98. CrossRef Medline

Hafner M, Landthaler M, Burger L, Khorshid M, Hausser J, Berninger P, Rothballer A, Ascano M Jr, Jungkamp AC, Munschauer M, Ulrich A, Wardle GS, Dewell S, Zavolan M, Tuschl T (2010) Transcriptome-wide identification of RNA-binding protein and microRNA target sites by PAR-CLIP. Cell 141:129-141. CrossRef Medline

Jønson L, Vikesaa J, Krogh A, Nielsen LK, Hansen Tv, Borup R, Johnsen AH, Christiansen J, Nielsen FC (2007) Molecular composition of IMP1 ribonucleoprotein granules. Mol Cell Proteomics 6:798-811. CrossRef Medline

Jung H, Yoon BC, Holt CE (2012) Axonal mRNA localization and local protein synthesis in nervous system assembly, maintenance and repair. Nat Rev Neurosci 13:308-324. CrossRef Medline

Kimmel CB, Ballard WW, Kimmel SR, Ullmann B, Schilling TF (1995) Stages of embryonic development of the zebrafish. Dev Dyn 203:253-310. CrossRef Medline

Kislauskis EH, Zhu X, Singer RH (1994) Sequences responsible for intracellular localization of beta-actin messenger RNA also affect cell phenotype. J Cell Biol 127:441-451. CrossRef Medline

Kundel M, Jones KJ, Shin CY, Wells DG (2009) Cytoplasmic polyadenylation element-binding protein regulates neurotrophin-3-dependent beta-catenin mRNA translation in developing hippocampal neurons. J Neurosci 29:1363013639. CrossRef Medline

Lasek RJ, Dabrowski C, Nordlander R (1973) Analysis of axoplasmic RNA from invertebrate giant axons. Nat New Biol 244:162-165. CrossRef Medline

Lecaudey V, Ulloa E, Anselme I, Stedman A, Schneider-Maunoury S, Pujades C (2007) Role of the hindbrain in patterning the otic vesicle: a study of the zebrafish vhnf1 mutant. Dev Biol 303:134-143. CrossRef Medline

Lécuyer E, Yoshida H, Parthasarathy N, Alm C, Babak T, Cerovina T, Hughes TR, Tomancak P, Krause HM (2007) Global analysis of mRNA localization reveals a prominent role in organizing cellular architecture and function. Cell 131:174-187. CrossRef Medline

Lee SK, Hollenbeck PJ (2003) Organization and translation of mRNA in sympathetic axons. J Cell Science 116:4467-4478. CrossRef Medline

Leung KM, van Horck FP, Lin AC, Allison R, Standart N, Holt CE (2006) Asymmetrical beta-actin mRNA translation in growth cones mediates attractive turning to netrin-1. Nat Neurosci 9:1247-1256. CrossRef Medline

Lyons DA, Pogoda HM, Voas MG, Woods IG, Diamond B, Nix R, Arana N, Jacobs J, Talbot WS (2005) erbb3 and erbb2 are essential for Schwann cell migration and myelination in zebrafish. Curr Biol 15:513-524. CrossRef Medline

Lyons DA, Naylor SG, Scholze A, Talbot WS (2009) Kiflb is essential for mRNA localization in oligodendrocytes and development of myelinated axons. Nat Genet 41:854-858. CrossRef Medline

Meer EJ, Wang DO, Kim S, Barr I, Guo F, Martin KC (2012) Identification of a cis-acting element that localizes mRNA to synapses. Proc Natl Acad Sci U S A 109:4639-4644. CrossRef Medline

Nagai T, Ibata K, Park ES, Kubota M, Mikoshiba K, Miyawaki A (2002) A variant of yellow fluorescent protein with fast and efficient maturation for cell-biological applications. Nat Biotechnol 20:87-90. CrossRef Medline

Nédelec S, Peljto M, Shi P, Amoroso MW, Kam LC, Wichterle H (2012)
Concentration-dependent requirement for local protein synthesis in motor neuron subtype-specific response to axon guidance cues. J Neurosci 32:1496-1506. CrossRef Medline

Patel VL, Mitra S, Harris R, Buxbaum AR, Lionnet T, Brenowitz M, Girvin M, Levy M, Almo SC, Singer RH, Chao JA (2012) Spatial arrangement of an RNA zipcode identifies mRNAs under post-transcriptional control. Genes Dev 26:43-53. CrossRef Medline

Roche FK, Marsick BM, Letourneau PC (2009) Protein synthesis in distal axons is not required for growth cone responses to guidance cues. J Neurosci 29:638-652. CrossRef Medline

Ross AF, Oleynikov Y, Kislauskis EH, Taneja KL, Singer RH (1997) Characterization of a beta-actin mRNA zipcode-binding protein. Mol Cell Biol 17:2158-2165. Medline

Shaner NC, Campbell RE, Steinbach PA, Giepmans BN, Palmer AE, Tsien RY (2004) Improved monomeric red, orange and yellow fluorescent proteins derived from Discosoma sp. red fluorescent protein. Nat Biotechnol 22:1567-1572. CrossRef Medline

Steward O, Levy WB (1982) Preferential localization of polyribosomes under the base of dendritic spines in granule cells of the dentate gyrus. J Neurosci 2:284-291. Medline

Taylor AM, Berchtold NC, Perreau VM, Tu CH, Li Jeon N, Cotman CW (2009) Axonal mRNA in uninjured and regenerating cortical mammalian axons. J Neurosci 29:4697-4707. CrossRef Medline

Thermes V, Grabher C, Ristoratore F, Bourrat F, Choulika A, Wittbrodt J, Joly JS (2002) I-SceI meganuclease mediates highly efficient transgenesis in fish. Mech Dev 118:91-98. CrossRef Medline

Twiss JL, Smith DS, Chang B, Shooter EM (2000) Translational control of ribosomal protein $\mathrm{L} 4 \mathrm{mRNA}$ is required for rapid neurite regeneration. Neurobiol Dis 7:416-428. CrossRef Medline

Verma P, Chierzi S, Codd AM, Campbell DS, Meyer RL, Holt CE, Fawcett JW (2005) Axonal protein synthesis and degradation are necessary for efficient growth cone regeneration. J Neurosci 25:331-342. CrossRef Medline

Weiner OD, Zorn AM, Krieg PA, Bittner GD (1996) Medium weight neurofilament mRNA in goldfish Mauthner axoplasm. Neurosci Lett 213:8386. CrossRef Medline

Willis DE, van Niekerk EA, Sasaki Y, Mesngon M, Merianda TT, Williams GG, Kendall M, Smith DS, Bassell GJ, Twiss JL (2007) Extracellular stimuli specifically regulate localized levels of individual neuronal mRNAs. J Cell Biol 178:965-980. CrossRef Medline

Yao J, Sasaki Y, Wen Z, Bassell GJ, Zheng JQ (2006) An essential role for beta-actin mRNA localization and translation in $\mathrm{Ca}^{2+}$-dependent growth cone guidance. Nat Neurosci 9:1265-1273. CrossRef Medline

Zhang HL, Eom T, Oleynikov Y, Shenoy SM, Liebelt DA, Dictenberg JB, Singer RH, Bassell GJ (2001) Neurotrophin-induced transport of a betaactin mRNP complex increases beta-actin levels and stimulates growth cone motility. Neuron 31:261-275. CrossRef Medline

Zheng JQ, Kelly TK, Chang B, Ryazantsev S, Rajasekaran AK, Martin KC, Twiss JL (2001) A functional role for intra-axonal protein synthesis during axonal regeneration from adult sensory neurons. J Neurosci 21:92919303. Medline

Zivraj KH, Tung YC, Piper M, Gumy L, Fawcett JW, Yeo GS, Holt CE (2010) Subcellular profiling reveals distinct and developmentally regulated repertoire of growth cone mRNAs. J Neurosci 30:15464-15478. CrossRef Medline 